\title{
OVERVIEW OF DRUG REGISTRATION REQUIREMENTS FOR PHARMACEUTICALS IN EMERGING MARKET
}

\author{
Jitendra Kumar Badjatya* \\ Department of Pharmacy, J.J.T University, Chudela, Jhunjhunu, Rajasthan. India \\ *Corresponding Author's E-mail: - jeetbadjatya@gmail.com
}

\begin{abstract}
Pharmaceutical product registration is a demanding task in regulated, semi regulated and rest of world countries. Although the requirements are harmonized in regulated countries by CTD (Common technical document) filing, yet others have enormous diversity in requirements.ICH (International conference on Harmonization of Technical Requirements for Registration of Pharmaceuticals for Human Use) brought regulatory authorities and pharmaceutical industries of Europe, Japan and US together for various aspects of drug registration. Similarly, countries from Asia pacific and gulf are in process of harmonization with mutual concern as The Association of Southeast Asian Nations (ASEAN) and Gulf Co-operation Council (GCC). The optimization in requirements is mandatory and can be judged by the incidence of higher cost involved in availability of drugs, research and development facilities. For better treatment safety and efficacy for the drugs must be justified and rationalize for public security. The quality, safety and efficacy data has its own importance in the registration dossier. The commercial significance of markets is increasing globally. It is vital for pharmaceutical industry to cope with the regulatory requirements for betterment of public and to ensure their place in the market. This paper approaches the registration requirements in the form a dossier for market authorization. It also has drawn a comparative statement on various approaches for harmonization of registration requirement for pharmaceuticals.

Keywords: ASEAN, GCC, BMR, CIS, DMF, ICH, FP
\end{abstract}

\section{INTRODUCTION:}

Asia is expected to overtake Europe in pharmaceutical market within the next decade and sales are driven by growth in key emerging markets. e.g., China is deemed to be the second largest pharmaceutical market after the United States by 2015 . More than $85 \%$ population lives in the emerging market and so the real economic growth has come from these markets. This promotes many MNC's switched to these emerging countries particularly in China, India, Russia, Korea and Mexico.

The growing presence is increasingly moving beyond the use of CRO's and marketing of well established products to include early-stage research and technology aimed at specific medical needs of patients in these regions. One way to launch new drugs in a timely manner in emerging markets is to include majority of patients from relevant countries in clinical development programmes. This practice is routine for most pharmaceutical companies. These development programmes attributed to longer life expectancy and lifestyle changes that are possible through rapid economic growth.

Emerging markets are important and expanding globally and are raising demand for general and lifesaving medicines. Regional cooperation is required to ensure that the scientific capacity is developed. Apart from this, regional manufacturing capacity is the most expected way to enable economic feasibility, specified quality standards and meets international export requirements. Legislative and political factors are the most critical one, countries need to have support to develop effective national legislation, as well as cooperating regionally which helps to access to essential medicines.

Emerging Markets: (ROW excluding ANZ)

Rest of the World (Asia Pacific except Japan, ANZ, GCC, LATAM, CEE, CIS)

(C) 2011, JDDT. All Rights Reserved
(LATAM: Latin America; CEE - Central East Europe; CIS - Commonwealth of Independent States; ANZ - Australia, New Zealand; GCC -Gulf Co-operation Council; ROW Rest of World)

This market consists of mainly the countries from Asia pacific, Latin America, Eastern Europe, Africa and Gulf countries. These countries are not differing in their region but also in many other aspects as regulation of Pharmaceuticals, Using different Guidelines for registration, registration fees, Requirements to maintain registration, Patent regulation and legislation for the drug.

The Asia Pacific market is expected to grow from USD 187 billion in 2009 to nearly USD 275 billion in 2013, at a CAGR of $13 \%$. This is mainly due to low cost availability of generic medicines, rising income, growth of business and health insurance schemes.

The optimization in requirements is mandatory and can be judged by the incidence of higher cost involved in availability of drugs, research and development facilities. For better treatment safety and efficacy for the drugs must be justified and rationalize for public security. The quality, safety and efficacy data has its own importance in the registration dossier. The commercial significance of markets is increasing globally

WHO is continuing to play a major role in terms of scientific capacity development, through its prequalification project and other activities? Given that the quality of pharmaceuticals is such a major issue, the WHO and other international organizations, such as developed country drug regulatory authorities, should be encouraged and supported to expand their current programmes which are supporting to developing countries. Ministry of Health of GCC states (Bahrain, Kuwait, Oman, Qatar, Saudi Arabia and UAE) are regulatory authorities for the regional ISSN: 2250-1177
CODEN (USA): JDDTAO 
pharma sector. They also regulate prices of pharmaceutical products and bring about harmonization of varying prices and the regulatory process, the GCC implemented a centralized system, Gulf Central Committee for Drug Registration (GCC-DR) in May 1999, which currently runs parallel to the regulatory regimes in the region. The Latin American markets are forecast to grow at a robust $10 \%$ CAGR from USD 37.6 billion in 2009 to USD 62 billion in 2012, due to changes in regulatory policies and increased manufacturing base for generic drugs by the US drug makers. Strong economic growth in these countries will drive lucrative growth in these markets.

The regulatory regime in LATAM countries can be divided into three categories i.e. Countries which have established regulations (Brazil, Mexico, and Venezuela) to demonstrate the efficacy, safety through clinical trials or Bioequivalence studies with the innovator's product in the drug approval process. The countries as Argentina, Chile, Columbia, Ecuador, and Paraguay also have the regulations for registration of new or generic drug but are less stringent from first category. The last category of countries (Guatemala, Barbados, Bolivia, Nicaragua and Peru) has imperfectly formed drug regulations for the approval of drugs. Rest of the region / countries insist on following ICH region for some data like stability, clinical trials though it follows majorly its own regulations e.g., the ASEAN countries require data as per ASEAN CTD which is same as ICH CTD for data requirements organized in Parts. The brief contents of CTD and major requirements for various regions are tabulated in Table (1).

Table 1: Structure of Common Technical Document (CTD)

\begin{tabular}{|l|l|l|l|}
\hline \multicolumn{1}{|c|}{ ICH CTD } & \multicolumn{1}{|c|}{$\begin{array}{c}\text { ASEAN } \\
\text { CTD }\end{array}$} & \multicolumn{1}{|c|}{ Description } & \multicolumn{1}{|c|}{ Remarks } \\
\hline $\begin{array}{l}\text { Module 1-Regional } \\
\text { and Administrative } \\
\text { Information }\end{array}$ & Part I & $\begin{array}{l}\text { Contains documents that are specific to each region. This } \\
\text { module is not part of CTD. Basically consists of administrative } \\
\text { documents like Application form, legal documents (GMP, } \\
\text { Licenses etc.), labeling etc. }\end{array}$ & $\begin{array}{l}\text { Required for } \\
\text { generics and New } \\
\text { Drug }\end{array}$ \\
\hline $\begin{array}{l}\text { Module 2 - Overall } \\
\text { Summary }\end{array}$ & Part II & $\begin{array}{l}\text { This module summarizes the Module 3, 4 and 5. It includes } \\
\text { Quality Overall summary, Non Clinical Overview and Summary } \\
\text { and Clinical Overview and Summary. The summary provides } \\
\text { reviewer the abstract of documents provided in the whole } \\
\text { application }\end{array}$ & $\begin{array}{l}\text { Required for } \\
\text { generics and New } \\
\text { Drug. For generics } \\
\text { summary on } \\
\text { Quality part only } \\
\text { required }\end{array}$ \\
\cline { 3 - 4 } Module 3 - Quality & $\begin{array}{l}\text { The documents related to Chemistry, manufacturing and Control } \\
\text { of both Drug Substance and Drug Product is included in this } \\
\text { module. }\end{array}$ & $\begin{array}{l}\text { Required for } \\
\text { generics and New } \\
\text { Drug }\end{array}$ \\
\hline Module 4 - Safety & Part III & $\begin{array}{l}\text { Non Clinical Study Reports - Data on pharmacologic, } \\
\text { pharmacokinetic, and toxicological evaluation of the } \\
\text { pharmaceutical product is provided. }\end{array}$ & $\begin{array}{l}\text { Not required for } \\
\text { generics }\end{array}$ \\
\hline $\begin{array}{l}\text { Module 5 - } \\
\text { Efficacy }\end{array}$ & Part IV & $\begin{array}{l}\text { Clinical Study Reports - A critical assessment of the clinical data } \\
\text { and related reports is provided in this module. }\end{array}$ & $\begin{array}{l}\text { Not required for } \\
\text { generics except } \\
\text { Bioequivalence } \\
\text { study }\end{array}$ \\
\hline
\end{tabular}

\section{Research and Development focus}

With the growing emphasis on the timely introduction of life saving drugs for diseases in Asia, there has also been an increase in discovery research for diseases that are more prevalent in the region than in the United States and in Europe.

\section{Emerging Markets: Key Challenges}

- Lack of harmonization in regulatory requirements:

- Absent, new or changing regulations

- Lack of quality manufacturing capacity and differences in Labeling

- Emerging market health authorities have limited resources

- Lack of effective legislation to allow use of so-called 'TRIPs flexibilities' such as compulsory licensing.
- They require local patients in clinical trials/ B.E study to participate. Patient may/may not participate in Phase I

- Lack of adequate human resources and funding for drug regulatory activities.

- Lack of adequate regulatory science capacity to assess generic products that potentially meet the need for essential drugs.

- Lack of formal pre-submission meetings or scientific advice.

- Long review timelines for registration hence more uncertainty.

- More detailed documentation, SOPs, validation requests

- More requests for inspections, (Lack of mutual recognition of $\mathrm{ICH}$ countries and amongst countries within region) 
Badjatya et al

Journal of Drug Delivery \& Therapeutics; 2013, 3(2), 227-232

\section{Regulatory Barriers}

There are key regulatory barriers affecting the drug lag witnessed in the emerging countries. These barriers are Western approval, CPP, GMP, pricing approval, document authentication and harmonisation. These barriers need to be overcome in order to reduce drug lag further in the future.

\section{Strategy for Success}

* Proper Time management as the registration and company success depends upon the time taken by product to reach the market first

* Know and be compliant with national requirements
* Health authority relationships critical, local talent important

* Training programmes and incentives for agency staff

* Frequent and early communication with Health Authorities

* Early integration of emerging market strategy into development plans and integration of regional requirements into a global regulatory plan

* Rapid responses and rapid publishing support 24/7.

* Be the first with a product for an unmet medical indication and proper invest in the region

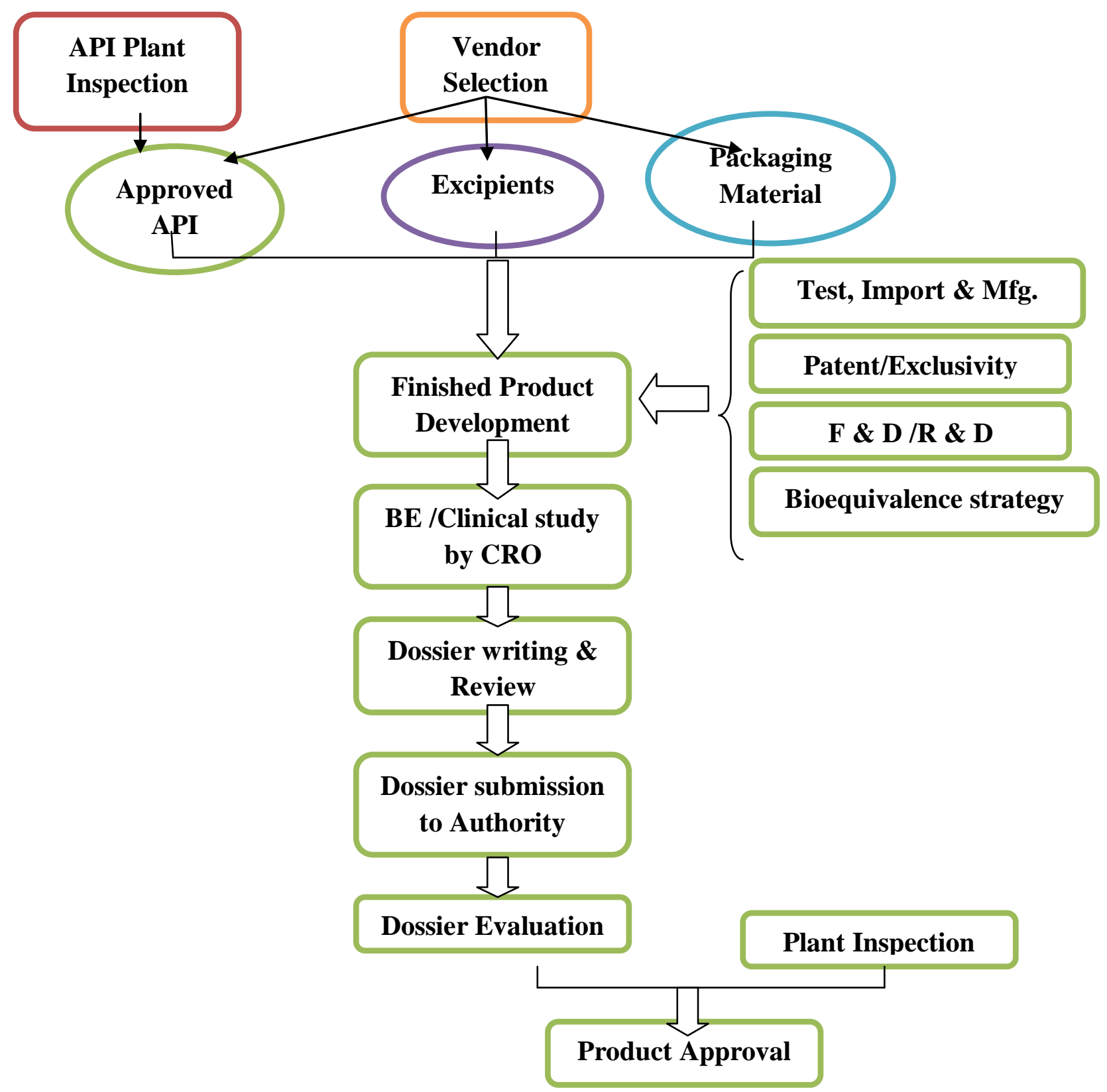

Figure: 1 Regulatory Filing Process 
Table 2: Data requirements of different regions

\begin{tabular}{|c|c|c|c|c|c|}
\hline $\begin{array}{c}\text { Registration } \\
\text { Requirements } \\
\end{array}$ & ASEAN & GCC & LATAM & CIS & $\begin{array}{c}\text { Asia Pacific } \\
\text { (except ASEAN) }\end{array}$ \\
\hline $\begin{array}{l}\text { Site } \\
\text { registration }\end{array}$ & Yes & $\overline{\text { Yes }}$ & $\overline{\text { Yes }}$ & Yes & Yes \\
\hline $\begin{array}{l}\text { Plant GMP } \\
\text { approval }\end{array}$ & $\begin{array}{l}\text { Accepts } \\
\text { FDA/EU/PICs } \\
\text { approval for FP site. }\end{array}$ & $\begin{array}{l}\text { Audit by GCC } \\
\text { member countries of } \\
\text { FP site }\end{array}$ & $\begin{array}{lr}\text { Major } & \text { countries do } \\
\text { audit. } & \text { (Brazil, } \\
\text { Mexico, Colombia) }\end{array}$ & $\begin{array}{l}\text { Audit by CIS } \\
\text { member countries of } \\
\text { FP site }\end{array}$ & $\begin{array}{l}\text { Accepts } \\
\text { FDA/EU/PICs } \\
\text { approval for FP } \\
\text { site. }\end{array}$ \\
\hline $\begin{array}{l}\text { Stability } \\
\text { Zone }\end{array}$ & Zone IV $\mathrm{a}$ and IV $\mathrm{b}$ & Zone IV a & $\begin{array}{l}\text { Zone II and Zone IV } \\
\mathrm{b}\end{array}$ & Zones I and II & Zone I to Zone IV \\
\hline $\begin{array}{l}\text { Stability } \\
\text { requirements }\end{array}$ & $\begin{array}{l}300 \pm \\
175 \% \pm 5 \% \mathrm{RH}\end{array}$ & $\begin{array}{l}300 \pm 20 \mathrm{C}, 65 \% \quad \pm \\
5 \% \mathrm{RH}\end{array}$ & 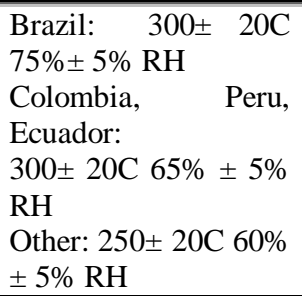 & $\begin{array}{l}250 \pm 20 \mathrm{C} 60 \% \pm 5 \% \\
\mathrm{RH}\end{array}$ & $\begin{array}{l}250 \pm 20 \mathrm{C} 60 \% \\
5 \% \text { RH (Zones I } \\
\text { and II) } \\
300 \pm 20 \mathrm{C} 65 \% \quad \pm \\
5 \% \text { RH (Zones III } \\
\text { and IV a) } \\
300 \pm 20 \mathrm{C} 75 \% \quad \pm \\
5 \% \text { RH (Zone IV b) }\end{array}$ \\
\hline $\begin{array}{l}\text { No. of } \\
\text { submission } \\
\text { Batches } \\
\end{array}$ & 3 pilot scale & 3 pilot scale & 3 pilot scale & $\begin{array}{c}\text { primary batches, } \\
\text { out of which min } 2 \\
\text { are Pilot scale }\end{array}$ & $\begin{array}{l}3 \text { primary batches, } \\
\text { out of which min } 2 \\
\text { are Pilot scale }\end{array}$ \\
\hline Stability data & 12 months & 12 months & 6-12 months & 12 months & 12 months \\
\hline $\begin{array}{l}\text { Stability } \\
\text { guidelines } \\
\text { reference } \\
\end{array}$ & ASEAN & $\overline{\mathrm{GCC}}$ & ANVISA and ICH & $\mathrm{ICH}$ & ICH/WHO \\
\hline $\begin{array}{l}\text { BE Study (for } \\
\text { Generic) }\end{array}$ & $\begin{array}{l}\text { Against US } \\
\text { /EU/Australia } \\
\text { reference drug in any } \\
\text { Country except } \\
\text { Thailand, where BE } \\
\text { to be done locally. } \\
\text { PE to be done against } \\
\text { local reference } \\
\text { product in some } \\
\text { countries. }\end{array}$ & $\begin{array}{l}\text { Against } \\
\text { /EU/Australia } \\
\text { reference drug in } \\
\text { any Country. }\end{array}$ & $\begin{array}{l}\text { Brazil: Against Brazil } \\
\text { reference drug in any } \\
\text { CRO approved by } \\
\text { ANVISA. PE to be } \\
\text { done in Brazil } \\
\text { Mexico: Against } \\
\text { Mexican reference, in } \\
\text { Mexico Only. } \\
\text { Others: The BE for } \\
\text { Brazil /Mexico is } \\
\text { normally accepted. }\end{array}$ & $\begin{array}{l}\text { Reference drug in } \\
\text { any Country where } \\
\mathrm{BE} \text { to be done } \\
\text { locally. PE to be done } \\
\text { against local } \\
\text { reference product in } \\
\text { some countries. }\end{array}$ & $\begin{array}{l}\text { Reference drug in } \\
\text { any Country where } \\
\mathrm{BE} \text { to be done } \\
\text { locally. PE to be } \\
\text { done against local } \\
\text { reference product in } \\
\text { some countries. } \\
\text { Published Literature } \\
\text { data eg Sri Lanka, } \\
\text { Nepal, Bangladesh }\end{array}$ \\
\hline Major holdup & $\begin{array}{l}\text { Obtaining Certificate } \\
\text { of Pharmaceutical } \\
\text { product (CPP) may } \\
\text { delay the process, } \\
\text { Administrative } \\
\text { procedures in } \\
\text { individual countries, } \\
\text { time delay in } \\
\text { approval }\end{array}$ & $\begin{array}{lr}\text { Delay } & \text { in } \\
\text { registrations. } & \\
\text { Administrative } & \\
\text { issues with local } \\
\text { regulatory and } \\
\text { country laws. }\end{array}$ & $\begin{array}{lr}\text { CPP, Legalizations, } \\
\text { Translations, } & \text { GMP } \\
\text { audits, } & \text { local } \\
\text { requirements, } & \text { time } \\
\text { delay } & \end{array}$ & $\begin{array}{l}\text { Legalizations, } \\
\text { Translations, Fund, } \\
\text { Registration cost, } \\
\text { Document and time } \\
\text { delay }\end{array}$ & $\begin{array}{l}\text { Regulatory delays, } \\
\text { Require strong IP } \\
\text { laws, Better training } \\
\text { is needed }\end{array}$ \\
\hline $\begin{array}{l}\text { Dossier } \\
\text { Format } \\
\end{array}$ & ACTD & CTD & Country specific & $\begin{array}{l}\text { Country specific } \\
\text { (resemble CTD) }\end{array}$ & Country specific \\
\hline $\begin{array}{l}\text { Registration } \\
\text { time }\end{array}$ & 12-24 months & 24-36 months & $\begin{array}{c}\text { Varies from } 7 \text { days in } \\
\text { Peru to } 24 \text { months in } \\
\text { Brazil }\end{array}$ & $\begin{array}{c}\text { 6-24 months } \\
\text { Russia } 18 \text { months } \\
\text { Belarus-180 working } \\
\text { days }\end{array}$ & 8-24 months \\
\hline
\end{tabular}

\section{Harmonization:}

It is evident that a lack of harmonisation between countries can lead to unnecessary duplication of work and waste of valuable resources and eventually increase drug lag. The first harmonisation was initiated by the Association of South East Asian Nations (ASEAN) in 1967. This harmonization occurs in clusters e.g. ASEAN and Gulf Countries but this should be reformed after translation. Format for marketing application resembles with the old EU submission format and is not officially decided yet. Few countries as India, Ukraine, Russia, South Africa etc. uses the format almost same as EU-CTD format. Which also seems to become harmonized in regards of formats.

Harmonisation in GMP will also help to improve pharmaceutical trade between ASEAN member countries by removing impeding barriers.

The countries from Asia pacific and Gulf have almost harmonized their regulatory environment through the Association of Southeast Asian Nations (ASEAN) and Gulf Co-operation Council (GCC) organizations, rest of the regions are yet to come up with the harmonized regulations in their respective regions. 


\section{Result and Conclusion:}

A comparison against the registration requirements for different group of emerging countries has been done to judge the difference in regulatory requirements of different countries. Since the world is divided in the drug approval procedures, it is important for the manufacturers, especially the generic companies, to carefully assess the market interest, cost of development, target regions, regulatory requirements before the development of drugs.

By looking at the different regulatory environment, it is impractical to get global marketing approval at same time and launch in all the regions at one go. Hence, it is necessary to understand and define the clear regulatory strategy by looking at the target regions, different patent terms and its extension, various application possibilities, data requirements, deadlines for launching products to be marketed in different regions. This eliminates unnecessary studies, minimizes the delay in drug approvals and subsequent launch, and reduces overall cost of research and development.
Although the requirements are harmonized in regulated countries by CTD (Common technical document) filing, yet others have enormous diversity in requirements.ICH brought regulatory authorities and pharmaceutical industries of Europe, Japan and US together for various aspects of drug registration should bring some requirement to be harmonized there in emerging market, so that the drug approval process becomes easy and duplication of work and waste of valuable resources avoided. By examining these markets individually, it would be easier to target the areas where they can specifically improve their regulatory barriers, thus leading the way for the rest of the countries.

Finally, there needs to be a reassertion that the purpose of drug registration is to protect the public health, not to facilitate profit of pharmaceutical manufacturers. Registration should be seen as a critical step in ensuring access to safe and effective medicinal product. 


\section{REFERENCES:}

1. http://www.ncbi.nlm.nih.gov/pmc/articles/PMC3148610/

2. http://www.monitor.com/Portals/0/MonitorContent/imported/MonitorUnitedStates/Articles/PDFs/Monitor_Pharma_Prescription_ Launches_in_Emerging_Markets_083112.pdf

3. http://www.topra.org/sites/default/files/regrapart/1/4216/rethinking_emerging_markets_for_regulatory_affairs_morrison_singh.p $\mathrm{df}$

4. http://www.medpace.com/PDF/ConductingTrialsInChina.pdf

5. http://archive.baybio.org/files/1304031064.pdf

6. http://cirsci.org/system/files/private/Apr06\%20EM\%20Reg\%20Issues\%20and\%20Impact\%20on\%20Access_0.pdf

7. http://www.ipapharma.org/pt/sep2011/15-20.pdf

8. http://www.ich.org/cache/compo/276-254-1.html

9. http://www.ich.org

10. http://www.hc-sc.gc.ca/

11. http://www.asean.org

12. http://www.drugterm.com

13. http:// www.hsa.gov.sg

14. http://www.sgh.org.sa/registration.htm

15. http:// www.mccza.com 